\title{
Eerste treë in die Praktiese Teologie - waarheen?
}

\author{
T F J Dreyer \\ Universiteit van Pretoria
}

\begin{abstract}
First steps in practical theology

A new title, First steps in practical theology, has recently been released. This publication addresses the problem of the scientific base and methodology of this discipline. In accordance with the viewpoints of Zerfass, Firet, Van der Ven and others, the authors try to guide students to exercise practical theology from the perspective of empirical theology. This paper is an attempt to point out possible pitfalls in implementing this method of research without theological reservations. It is an aim to modify students' views in such a way as to overcome these dangers.
\end{abstract}

Praktiese Teologie is in vergelyking met die ander teologiese dissiplines nog in sy kinderskoene. In 1774 is Praktiese Teologie vir die eerste maal as universiteitsvak aan die Universiteit van Wenen ingestel. Geleidelik sou die vak met die gepaardgaande groeipyne ontwikkel tot 'n volwaardige vak. Schleiermacher het vir die Praktiese Teologie sy ensiklopediese posisie omlyn en 'n eie studieterrein probeer toeken, naamlik die teorie van die kerklike praxis (Janson 1982:326). Hierdie omlyning van Schleiermacher kon egter nie daarin slaag om die identiteitskrisis van die 'teologiese tiener' te besweer nie. Die worsteling om 'n eie wetenskaplike identiteit het hom afgespeel in 'n spanningsvolle heen-en-weer beweeg tussen die pole van die teorie en die praxis. Pogings is aangewend om hierdie pendulumbeweging te oorbrug deur dit te vervang met 'n bipolêre benadering (Heitink 1979), waarin daar in die spanningsveld van teorie en praxis gesoek word na die nodige balans, deur beide pole voortdurend op mekaar te laat inwerk.

Alhoewel die bipolêre benadering tans die grootste aanhang geniet, is daar selfs binne hierdie benaderingswyse nog steeds die moontlikheid van 'n polêre wanbalans as gevolg van waardes wat in modelle en ondersoekmetodes aan die onderskeie pole 
toegeken word. Heyns (in Heyns \& Pieterse 1990:96-97) onderskei daarom selfs vandag nog vier hoofstrome in die beoefening van die vak, naamlik die pragmatiese, pastoraal-teologiese, hermeneuties-teologiese en empiriese uitgangspunte. Indien die vier hoofstrome ondersoek word, vind ' $n$ mens dat die probleem in elke geval herlei kan word na 'n wanbalans tussen die pole van teorie en praxis.

Alle pogings wat aangewend is om die 'teologiese tiener' van sy identiteitskrisis te bevry, was tot 'n groot mate vrugteloos, want dit het weer skisofreniese trekke in die beofening van die vak gevestig. Die vraagstelling bet net 'n verskuiwing ondergaan. Die geboortepyne van die vak was veroorsaak deur die vraag na wetenskaplike erkenning: 'n Praktiese gerigtheid bet die vak van sy wetenskaplikheid beroof, daarom is gekies vir 'n teoretiese benadering. Binne die huidige wetenskapsdenke is ' $n$ praktiese gerigtheid nie 'n diskwalifikasie vir wetenskaplikbeid nie, maar 'n vereiste en juis daarom word 'n bipolêre model gebruik om die noodsaaklikheid van beide teorie en praxis te beklemtoon. Hierdie benadering bet egter 'n volgende identiteitskrisis veronrsaak: Kan die Praktiese Teologie nog aanspraak maak op erkenning as teologiese dissipline of moet dit eerder tuisgebring word onder die ander geesteswetenskappe? Die vraagstelling raak dus nie primèr die verbouding tussen teorie en praxis nie, maar lè verder terug op die vlak van meta- en basisteorieë. Indien die vak sy teologiese identiteit wil behou, sal sy vertrekpunte op basisteoretiese vlak uitgespel moet word en sal hierdie basisteorie in sy navorsingsmodel en metodologie verdiskonteer moet word. Indien dit nie gedoen word nie sal die Praktiese Teologie 'n Fremdkörper binne die teologie wees.

Praktiese Teologie het op Europese bodem reeds sy eerste treë as volwaardige wetenskap gegee. In Suid-Afrika was die eerste treë makliker omdat die wetenskaplikes hier die reeds gebaande weë, geskoei op die lees van Europese modelle, kon bewandel. Die publikasie van Heyns \& Pieterse (1990) is daarom prysenswaardig omdat dit die beoefening van die vak in Suid-Afrika op 'n stewige wetenskaplike basis plaas. Op Suid-Afrikaanse bodem het daar in die verlede publikasies verskyn (bv Janson 1982; Jonker 1981), wat die inleidingsvrae rakende die vakgebied behandel het. Die genoemde outeurs het egter veral op die vlak van meta- en basisteorieë beweeg en nie werklik 'n metodologie of 'n navorsingsmodel vir die aspirant navorser uitgespel nie. Dit is juis in hierdie opsig dat die publikasie van Heyns \& Pieterse (1990) baanbrekerswerk verrig, omdat dit die eerste publikasie is wat vanaf metateoretiese vlak, via basisteorieë, die student metodologies begelei tot die daarstelling van praktykteorieë. Die boek wil aspirant praktiese teoloë begelei om hulle eerste treë in die Praktiese Teologie met vaste tred te kan gee. Die verdienste van die werk is juis daarin geleë dat dit 'n duidelike basisteorie verskaf, 'n verantwoorde wetenskapsmodel poneer, en 'n metodologie ontwerp wat wetenskaplike ondersoek- 
metodes moontlik maak om verifieerbare resultate te verkry. In die publikasie is gebou op die ervaring en insigte van die bekendste wetenskaplikes op die terrein. Indien die treë soos uitgespel gevolg sal word, sal dit in Suid-Afrika die wetenskaplike karakter van die Praktiese Teologie bo alle twyfel vestig.

Dat hierdie 'eerste treë' wetenskaplik korrek is, staan bo verdenking. Met die bestudering van hierdie werk dring die vraag hom egter onwillekeurig aan die teoloog op: Waarheen gaan hierdie wetenskaplike treë die 'teologiese tiener' lei? Kan dit nie dalk lei tot die skisofrenie van 'n dissipline in die teologie wat eintlik nie meer daar hoort nie? 'n Mens merk nie hierdie gevaar met die eerste oogopslag op nie, omdat die outeurs as rype teoloë moontlike dwaalweë vermy. Vir die aspirant teoloog wat slaafs die 'eerste treë' navolg, wag daar egter 'n aantal kruispaaie sonder duidelike aanwysings. Indien die onervare navorser by sulke kruispaaie nie 'n duidelike teologiese padkaart het (basis- en metateorieë) waarop hy kan terugval nie, bestaan die moontlikheid dat hy ' $n$ weg sal volg wat hom in sy navorsingsresultate by ' $n$ bestemming sal bring wat teologies onherkenbaar is.

Hierdie artikel is 'n poging om met die outeurs (Heyns \& Pieterse) in gesprek te tree oor die 'eerste treё'. In geheel gesien, is die voorgestelde teorieë en navorsingsmetodologie korrek en prysenswaardig. Op sommige punte langs die weg is duideliker aanwysings, myns insiens, noodsaaklik indien die Praktiese Teologie sy aanspraak as teologiese dissipline wil behou. Dit mag natuurlik wees dat die outeurs van mening is dat die vak nie noodwendig as teologiese dissipline beoefen hoef te word nie. Standpunte soos gereflekteer in die publikasie, is soms dubbelsinnig en kan na beide kante geïnterpreteer word.

Daar sal gepoog word om bepaalde uitgangspunte wat myns insiens duideliker omlyn moet word krities te evalueer en alternatiewe voor te stel.

\section{WAT IS TEOLOGIE?}

Indien die Praktiese Teologie as teologiese dissipline beoefen word, is die eerste vraag wat op basisteoretiese vlak beantwoord moet word, die vraag na die wese van teologie. Heyns (in Heyns \& Pieterse 1990:4) gee die volgende definisie van teologie: 'Teologie sou daarom beskryf kon word as die wetenskaplike bestudering van mense se geloof in God en mense se geloofsuitsprake oor God.' Hy beroep hom ter motivering op die uitspraak van Firet (1975:378-380) wat gesê het dat as dit nie was vir die geloof en geloofsbeslissing van mense nie, sou teologie as studieveld nooit bestaan het nie. Op sigself gesien, is dit natuurlik waar. God kan nooit werklik die objek van teologiese besinning wees nie, want God is nie objektief aanwysbaar of ontleedbaar nie. Die teologie kan hom hoogstens besig hou met menslike refleksie aangaande hulle geloofservaring met God. 
Die teologiese debat oor die wetenskaplike karakter van die teologie, wat so oud is as die teologie self, het in ons tyd 'n nuwe stimulus gekry vanweë paradigmatiese verskuiwings en kenteoretiese insigte wat op die teologie as wetenskap van toepassing gemaak word.

Van Huyssteen (1986) het met sy 'kritiese realisme' die nuwe wetenskapsfilosofiese denke vir die teologie diensbaar probeer maak. Daardeur bevry hy die teologie van die dwang van die positivisme en maak hy dit duidelik dat die wetenskaplike geloofwaardigheid van die teologie nie meer 'n probleem hoef te wees nie. Hierdie nuwe metateoretiese begronding is ook deur sommige praktiese teoloë gretig aangegryp as 'n wetenskapsmodel wat die teologie in die algemeen en die Praktiese Teologie in die besonder, wetenskaplike geloofwaardigheid kan verleen (Van Wyk 1989:147-190). 'n Normatief-deduktiewe benadering word afgewys en daar word gekies vir Praktiese Teologie wat as empiriese teologie beoefen moet word 'wat die werklikheid bestudeer vanuit die geloofsaspek en nie slegs vanuit bepaalde kerklike tradisies nie' (Van Wyk 1989:189). Die geloofsaspek is hier slegs 'n modale begrensing wat die Praktiese Teologie afgrens van die Psigologie of die Sosiologie. Hierdie gedagterigting vind volgens Van Wyk (1989:188) aansluiting by die denke van Gert Otto cum suius, wat die Praktiese Teologie as empiriese teologie wou vestig. Otto beskou Praktiese Teologie as 'kritische Theorie religiös vermittelter Praxis in der Gesellschaft' (Otto 1975:9-31). De Wet (1978:5-11) wys tereg daarop dat die standpunt van Otto berus op die siening dat Christelike teologie nie anders as op die basis van 'n algemene teologie van die godsdienste bedryf kan word nie. 'Hiermee laat hy vanselfsprekend ook die Skrif as bron en norm van die teologie los en vervang dit met die algemene godsdiensgeskiedenis as bron van sy teologie' (De Wet 1978:6). Velthuysen (1987:205-231) spreek sy waardering uit vir die gedagtes van Van Huyssteen, maar waarsku ook tegelyk teen die gevare wat dit vir die teologie kan inhou. Dit word volgens hom ' $n$ wesenlike vraag of in hierdie model die diensbaarheid van die teologie aan die kerklike verkondiging nog ter sprake is. In hierdie verband is dit belangrik om aandag te skenk aan enkele waarskuwende opmerkings wat Velthuysen (1987:229-231) in sy kritiek uitwys:

Die teologie is 'n kerklike besigheid - histories en prakties...ter wille van die kerk en sy verkondigingstaak. Losgemaak van hierdie verantwoordelikheid, kan dit moeilik anders as dat die teologie sal verword tot ' $n$ intellektuele spel wat op akademiese speelvelde sonder toeskouers in die pawiljoene gespeel word. Die houding van die teoloog is eksistensieel - een van 'commitment' en geloof. Enige teologiese ontwerp wat nie op radikale wyse hiermee rekening hou nie, is 'n hersenskim. Bowekonfessionaliteit word so maklik onkonfessionaliteit waar- 
mee die sinvolheid van die teologie as wetenskap ernstig in gedrang kom.

Met hierdie kursoriese opmerkings oor die gevare wat die nuwe wetenskapsmodelle vir die teologie en die Praktiese Teologie in die besonder kan inhou, wil ons terugkeer na die definisie van Heyns (in Heyns \& Pieterse 1990:4) oor die teologie: Volgens sy definisie bestudeer die teologie mense se geloof in God en mense se geloofsuitsprake oor God. Sonder enige verdere kwalifisering sou 'n mens met die definisie maklik tereg kan kom in die dampkring van die denke van Otto, wat die teologie as religie binne die godsdienswetenskap wil plaas. Mense se geloof en geloofsuitsprake oor God word dan ongekwalifiseerd die norm vir teologiese teorievorming. Alhoewel die Skrif erken word in die teorievorming, word dit gerelativeer en uitdruklik gestel dat teologie 'nie normatief funksioneer ten opsigte van die Praktiese Teologie nie' (Heyns \& Pieterse 1990:47). Dit is natuurlik korrek dat teologie as sodanig nie normatiewe waarde vir die Praktiese Teologie het nie, omdat binne die Reformatoriese denke die kerklike teologiese tradisie nie dieselfde gesag dra as die Skrif nie. Daarom is kerklike teologiese teorieë nie op sigself normatief nie en staan dit altyd oop vir korrigering. Aan die ander kant is teologie en teologiese teorieë nie onbelangrik nie, omdat dit refleksie is van die kerklike verstaan van die Skrif binne 'n bepaalde konteks. Die teologie is vir die praktiese teoloog ook 'n hulpmiddel om tot nuwe teorievorming binne 'n nuwe praxis te kom. As die normatiewe waarde van die teologie dus afgewys word, moet dit egter nie impliseer dat teologiese teorieë uit die verlede geen hulpfunksie het nie en moet dit ook nie die indruk wek dat teorieë wat wel norme vanuit die Skrif verwoord, by voorbaat verwerp moet word nie. In hulle keuse vir 'n empiriese benadering verset die outeurs hulle teen normatief-deduktiewe denke. Indien die teologie tot norm verhef word, is hulle korrek in hulle verset teen normatief-deduktiewe denke. Wanneer die deduktiewe metode egter aangewend word om vanuit die teologie bestaande teologiese teorieë te identifiseer, het die deduktiewe metode wel 'n funksie in die Praktiese Teologie. Die geïdentifiseerde teologiese teorieë het nie normatiewe waarde omdat dit herlei kan word na een of ander teologiese tradisie nie. Die normatiewe waarde van 'n teorie binne 'n bepaalde praxis sal eers bepaal kan word nadat die ondersoekproses voltooi is en die teologiese teorieë blootgestel is aan die wisselwerking met die praxis, waaruit 'n verstelde praktykteorie sal uitkristalliseer. Hierdie verstelde teorie sal dan hermeneuties aan die Skrif getoets moet word voordat dit vir die kerk normatiewe betekenis sal hè. Die normatiewe waarde lê dus nie in die teologie nie, maar in die eerste en laaste instansie in die Skrif self.

In hulle metodologie ruim hulle wel plek in dat daar 'n laaste evaluasiefase sal wees waarin die verstelde praktykteorie op hermeneutiese wyse met die bestaande 
prakties-teologiese teorie in interaksie gebring sal word. In hierdie terugkoppeling met die teologiese teorie spreek metateorieë en basisteorieë ook mee. As die teologie egter in 'n basisteorie bloot as die bestudering van geloofshandelinge beskryf word, het die normatiewe betekenis van die Skrif vir die teologie relatief geword. Geloofshandelinge van mense deur die eeue heen, ook dié in die praxis van vandag, het dus nou 'normatiewe status'. Daarom besluit die navorser aan watter geloofshandelinge hy in sy teorievorming deurgslaggewende gewig toeken. Dan is daar slegs 'n tydsverskil tussen geloofshandelinge wat in die Skrif betuig word en geloofshandelinge binne die huidige kerklike (of religieuse) praxis.

Hierin lề die gevaar vir die onervare navorser. As teologiese basisteorieë meespreek in die evaluering van verstelde praktykteorieë, moet die teologiese basisteorie skerper omlyn word sodat die unieke en normatiewe betekenis van die Skrif in die Praktiese Teologie as teologiese dissipline nie verlore raak of gerelativeer word nie. Van Wyk (1989:58-99) is korrek as hy 'n fundamentalistiese Skrifbeskouing en Skrifgebruik afwys wat objektiewe waarhede direk uit die Skrif aflei. 'n Pleitrede vir die behoud van die normatiewe waarde van die Skrif vir die teologie moet daarom nie meteen aan fundamentalisme gelykgestel word nie. Die praktiese teoloog wat teoloog wil bly en sy teologie ten dienste van die kerk wil beoefen, sal nie die uitdaging kan verbygaan om sy teorieë voortdurend in die hermeneutiese spanningsveld van die Skrif te bring nie. Grondliggend aan die geloofshandelinge van mense wat in die Skrif onder leiding van die Heilige Gees neerslag gevind het, le die aanspraak van God wat mense se handelinge in die geloof gerig en genormeer het. Daardie aanspraak van God moet hermeneuties vanuit die Skrif ontworstel word, hoe moeilik en versluierd dit ook al mag wees. Daardie grondwaarhede is die norma normans waaraan herstelde praktykteorieë gemeet moet word.

Om die gevaar soos hierbo uitgewys, te voorkom, sal 'n basisteorie vir die teologie dus ook iets moet verwoord van die normatiewe betekenis van die Skrif waarin die aanspraak van God se waarheid vir elke praxis telkens opnuut 'ontdek' sal moet word. Terugkoppeling na so 'n basisteorie sal die teologiese kwaliteit van die Praktiese Teologie waarborg. 'n Basisteorie wat ook die aspek van die normatiewe waarde van die Skrif verwoord, kan soos volg geformuleer word: Teologie is die wetenskaplike bestudering van mense se geloof in God en mense se geloofsuitsprake oor God, gemeet aan die aanspraak van God op mense soos dit betuig word in die Skrif.

\section{WAT IS PRAKTIESE TEOLOGIE?}

'n Volgende vraag wat van kardinale belang is, is op watter wyse 'n mens die vak Praktiese Teologie op die vlak van basisteorieë beskryf? Die outeurs behandel die aangeleentheid breedvoerig en kom dan uiteindelik tot die konklusie dat die Prak- 
tiese Teologie beskou kan word as 'n wetenskap wat hom besig hou met die bestudering van die teorieë wat ten grondslag lê van die kommunikatiewe geloofshandelinge in diens van die evangelie (Heyns \& Pieterse 1990:8). Hulle siening van die Praktiese Teologie is gebou op die uitsprake van Firet (1987:260). Volgens hierdie beskouing het die Praktiese Teologie nie soos die ander teologiese vakke primêr die Bybel as teks nie, maar is die gelowige mens die teks (Heitink 1979:22). Geloofshandelinge van mense voltrek sig in 'n kommunikatiewe handeling wat daarop gerig is om ander mense te help om God te ontmoet en met God en hulle medemens in gemeenskap te lewe. Die 'in diens van die evangelie' kwalifiseer die feit dat Praktiese Teologie deel is van die teologie omdat dit die bestudering van mense se geloof en geloofsuitsprake oor God is.

Vanuit die perspektief van Habermas se filosofie kombineer Pieterse (in Heyns \& Pieterse 1990:53) op metateoretiese vlak die sisteemteorie en die handelingsteorie tot kommunikatiewe handelingsisteme. 'Ons omskryf die Praktiese Teologie as die teologiese teorie omtrent kommunikatiewe handelingsisteme wat die koms van God in sy Woord tot die mens in sy wêreld intermediërend dien' (Heyns \& Pieterse 1990:54). Dit is duidelik dat Pieterse in sy basisteorie die teologiese konteks van die Praktiese Teologie nader wil kwalifiseer met 'die koms van God in sy Woord....' Die gewig wat daar aan die Woord toegeken word, blyk egter eers duidelik as gekyk word na die metodologie wat vir die Praktiese Teologie uitgespel word (daaroor later meer).

Dié basisteorie wat die gerigtheid van die vak op die praxis beklemtoon, is deur verskeie teoloë benut om die Praktiese Teologie as empiriese teologie te benader (Van der Ven 1988:13-14). 'n Empiriese benadering tot die vak hou groot voordele vir die vak in omdat dit werklik erns mak met die praxis waarin die geloofshandelinge voltrek moet word. Dit dwing ook die navorser om van wetenskaplike ondersoekmetodes gebruik te mak en tot verifieerbare resultate te kom. So 'n benadering dra ook inherent die moontlikheid dat die teologiese kwaliteit van die vak ongesiens ingeboet kan word. Jonker (1983:86) waarsku teen die ooraksentuering van een komponent ten koste van ander in die teologiese praxis. Hy verset hom teen 'n pragmatiese benadering waarin vanuit een analyse door middel van de sociale wetenschappen van de huidige stand van zaken, induktief naar het geheim van de theologie toe' beweeg word (Jonker 1983:14). Vanuit 'n totaliteitsvisie bepleit hy 'n benadering wat 'direk ingezet moet worden by de volheid van Gods heilshandelen in een veritatiewe en pneumatologische denkwijze' (Jonker 1983:85). Die Praktiese Teologie hou hom dan in die besonder besig met die verwerkliking van die Woord van God as Waarheid vir mense. 'Woorddynamiek en waarheidsworsteling ontmoe- 
ten elkaar in een interpolaire relatie. Dit is het vakgebied van de praktische theologie' (Jonker 1983:87).

Teen die agtergrond van die kontoere van die denke van Jonker lyk dit tog of die basisteorie van Pieterse die gevaar loop om induktief vanuit kommunikatiewe geloofshandelinge te kom tot by die geheim van die koms van God in sy Woord. Die gevaar skemer reeds deur as Pieterse op metateoretiese vlak vir 'n kommunikasieteorie kies wat hy dan op basisteoretiese vlak vir die Praktiese Teologie diensbaar wil maak. Dit word duidelik dat sy teologiese kwalifikasie van die 'koms van God in sy Woord' te vaag is en gevolglik oorheers word deur die kommunikasieteorie wat hy gebruik. Hy toets sy kommunikasieteorie aan teologiese kriteria in terme van 'koninkrykwaardes' (Heyns \& Pieterse 1990:36), en kom dan tot sekere gevolgtrekkings wat hy as vereistes vir 'n prakties-teologiese kommunikasieteorie poneer:

- Nie-outoritêre kommunikasie beteken dan dat mense as vrye mense op gelyke voet met mekaar kan kommunikeer en dialoogrolle moet kan wissel (Heyns \& Pieterse 1990:56). Op intermenslike vlak is dit natuurlik waar en die ideaal behoort sover as moontlik nagestreef te word. In die verhouding 'God en mens' kan die beginsel egter nie konsekwent toegepas word nie, omdat daar wel 'n moment aanbreek waar die mens met al sy vrae en antwoorde sal swyg en gelowig sal luister na die gesagvolle aanspraak van God. God verskaf nie noodwendig antwoorde op al ons vrae nie, maar in die ontmoetingsgebeure met God vervaag menslike vrae dikwels tot gelowige aanbidding (vgl Job).

- Onvoorwaardelike vryheid van die deelnemers is 'n kommunikatiewe vereiste wat beteken dat daar geen dwang bestaan nie: '[E]lkeen is vry om self oor 'n saak te besluit...' (Heyns \& Pieterse 1990:56). Vanuit 'n kommunikatiewe oogpunt is dit korrek dat op intermenslike vlak elke mens vry is om self oor 'n saak te besluit, maar vanuit 'n teologiese perspektief is menslike vryheid altyd 'n vryheid in verantwoordelikheid. Vryheid mag egter nooit misbruik word as 'n verskoning vir bandeloosheid nie (Gal 5:13). Vir die gelowige het menslike vryheid dus perke binne die kader van sy geloofsgehoorsaamheid aan God. Die aanspraak van God deur sy Woord en Gees 'dwing' mense ook dikwels tot ander insigte (Hand 9).

- Derdens geld 'n onvoorwaardelike aanvaarding van die ander as volwaardige mens en 'n erkenning van die ander se reg op 'n outentieke bestaan (Heyns \& Pieterse 1990:56). In die relasionele onderbou van elke kommunikatiewe handeling is onvoorwaardelike aanvaarding 'n vereiste. Aanvaarding van die mens beteken egter nie die sanksionering van sy outentieke bestaan nie. Goddelike 
'aanvaarding' beteken juis dat God die mens van sy sondige 'outentieke bestaan' wil bevry en wil bring tot 'n nuwe lewe volgens die wil van God (Ef 4:17-24).

Hierdie enkele voorbeelde illustreer genoegsaam dat die basisteorie wat vir die Praktiese Teologie verskaf word, nie die unieke kommunikatiewe verhouding tussen God en mens voldoende verreken nie, maar slegs konsentreer op kommunikatiewe geloofshandelinge van mense onderling. Die geloofsverhouding tussen God en mens is bepalend vir geloofshandelinge van mense onderling. Dit bevestig die waarskuwing van Jonker dat ons nie induktief-empiries vanuit menslike handelinge, hoe 'gelowig' dit ook al mag wees, kan uitkom by die geheim van God se waarheid nie.

Dit het tot gevolg dat 'n prakties-teologiese basisteorie, alhoewel daar op navorsingsvlak gestreef moet word na 'n balans en interaksie tussen teorie en praxis, iets moet verwoord van die teologiese 'wanbalans' dat selfs metateorieë moet buig voor die Waarheid van God. 'n Gewysigde basisteorie sou as volg geformuleer kan word: Praktiese Teologie bestudeer die kommunikatiewe geloofshandelinge van mense, gemeet aan die aanspraak van God op mense, soos dit betuig word in die Skrif.

\section{METODOLOGIESE MODELE}

By die onderneming van 'n navorsingsprojek in die Praktiese Teologie is dit noodsaaklik dat die navorsing van 'n bepaalde metodologiese model gebruik sal maak. 'Metodologiese modelle is modelle van 'n metode of werkswyse om die verkeer tussen teorie en praxis te vergemaklik en te bevorder' (Heyns \& Pieterse 1990:38). Heyns kies vir die model van Zerfass (1974:166) om die beweging tussen teorie en praxis te orden. In vereenvoudigde vorm kan hierdie model skematies as volg voorgestel word:

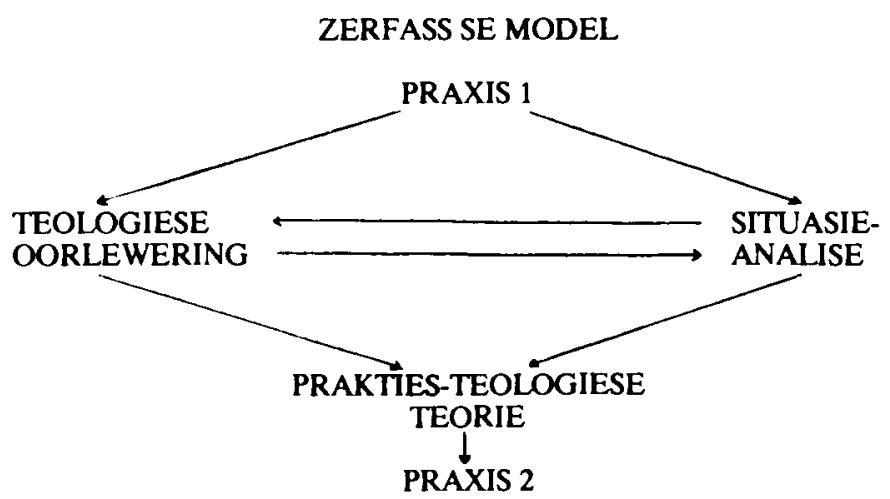


Om vanaf ' $n$ bestaande praxis (1) tot by ' $n$ nuwe praxis (2) te kom, is dit nodig dat teologiese oorlewering wat ten grondslag van die bestaande praktykteorieë lê, in die spanningsveld van die praxis van vandag gebring word. Hierdie praxis word empiries-analities met behulp van die kennis van ander wetenskappe ondersoek sodat 'n juiste beeld van die werklikheid verkry word. Vanuit die wisselwerking tussen die situasie-analise en die teologiese oorlewering word 'n nuwe prakties-teologiese teorie gevorm. Hierdie nuwe teorie word dan 'n praktykteorie wat op sy beurt 'n nuwe praxis tot gevolg sal hê. Die nuwe praxis word weer eens getoets aan beide die teologiese oorlewering en die situasie met die moontlikheid dat dit weer die praktykteorie kan wysig. So ontstaan dan uiteindelik 'n nuwe praxis wat die teologiese oorlewering en nuwe situasie geakkommodeer het.

Oppervlakkig beoordeel, wek dit die indruk van 'n model wat wetenskaplik verantwoord en teologies begrond is. Nadere ondersoek ontbloot egter die gebrekkige teologiese basis waarop die model gebou is. Dit is van deurslaggewende belang wat met die teologiese oorlewering bedoel word. Heyns (in Heyns \& Pieterse 1990:38) stel dat teologiese oorlewering betrekking het op kerklike tradisie, kerkgeskiedenis en al die ander teologiese dissiplines. Indien dit die interpretasie is en daarby gehou word, is dit bevredigend. Teologiese tradisies is gebind aan en gebore in ' $n$ bepaalde historiese konteks; daarom is dit op sigself nie normatief nie. Teologiese oorlewering sal binne elke nuwe praxis weer opnuut getoets en verwoord moet word.

As in ag geneem word dat Zerfass 'n Rooms-Katolieke teoloog is, vermoed ' $n$ mens dat hy die Skrif en teologiese oorlewering op dieselfde vlak sal plaas. Die 'eerste treë' van die outeurs trap juis in die slaggat van gelykstelling tussen Skrif en tradisie wanneer die teologiese teorie geïnterpreteer word as 'die Bybel, ander teologiese vakke en die geskiedenis van die kerk...' (Heyns \& Pieterse 1990:39). 'n Verder opmerking bevestig die vermoede as op bladsy 47 gesê word dat die Skrif vanweë sy ryke verskeidenheid en uiteenlopende Skrifmterpretasies, nie ongekwalifiseerd as bron vir die teorie-praxis verhouding beskryf en aangedui kan word nie. Die outeurs kom dan tot die gevolgtrekking dat die term 'Skrif' met 'teologie' vervang kan word. 'n Opmerking met dieselfde strekking word ook op bladsy $\mathbf{5 5}$ gevind as gesê word: 'Met teologiese tradisie bedoel ons die Skrif, die belydenisskrifte van die kerk en die interpretasie van die Skrif deur die eeue heen tot op vandag binne daardie kerklike tradisie.' In die model wat van Zerfass oorgeneem word, funksioneer die Skrif dus op dieselfde vlak as teologiese oorlewering en is dit blootgestel en/of uitgelewer aan die inspraak van die resultate van die empiriese analise.

As daar in die metodologie plek ingeruim word vir die terugkoppeling van die nuwe praktykteorie na beide die teologiese oorlewering en die situasie, is dit teolo- 
gies niksseggend omdat die Skrif op dieselfde vlak as die teologiese oorlewering gestel word en gevolglik vir korreksie oopstaan na die situasie. Daarom is hierdie model vir die onervare navorser gevaarlik omdat dit hom kan vervreem van sy teologiese basisteorie.

In 'n metodologiese model sal daar voorsiening gemaak moet word vir die onderskeid tussen teologiese oorlewering en die Skrif. In so 'n model kan die ondersoeker onbevange sy teologiese oorlewering aan die wisselwerking met die situasie blootstel. Dit sal die positiewe resultaat inhou dat teologiese tradisies weer eens vanuit 'n nuwe situasie krities ontleed en waar nodig gekorrigeer word. Sodoende sal die ontwerp van teologiese teorieë gedwing word om die toets van die relevansie in 'n nuwe situasie te deurstaan. Nuwe praktykteorieĕ sal dan in 'n metodologiese model ten slotte binne die hermeneutiese spanningsveld van die Skrif getoets moet word. Binne hierdie hermeneutiese spanningsveld sal God se aanspraak en sy Waarheid, soos dit neerslag gevind het en betuig is in menslike ervaringe in die Skrif, vanuit die vraagstelling van 'n nuwe praktykteorie ontworstel moet word.

Dit is 'n gekompliseerde saak waarby die hulp van die Bybelwetenskappe ingeroep sal moet word, maar by hierdie uitdaging kan die praktiese teoloog nie verbygaan nie. Indien 'n nuwe praktykteorie hierdie toets kan deurstaan, kan dit in die kerk tot 'n nuwe kerklike praxis lei. As dit nie die toets kan deurstaan nie, sal die praktykteorie so gewysig moet word dat dit, gemeet aan die Skrif, teologies houdbaar is. Slegs wanneer die metodologiese model ook vir hierdie teologiese kriterium voorsiening maak, kan die Praktiese Teologie teorieë vorm wat nog binne die ruimte van die teologie op erkenning kan aandring.

'n Gewysigde model wat erkenning verleen aan die normatiewe waarde van die Skrif, kan soos volg daar uitsien:

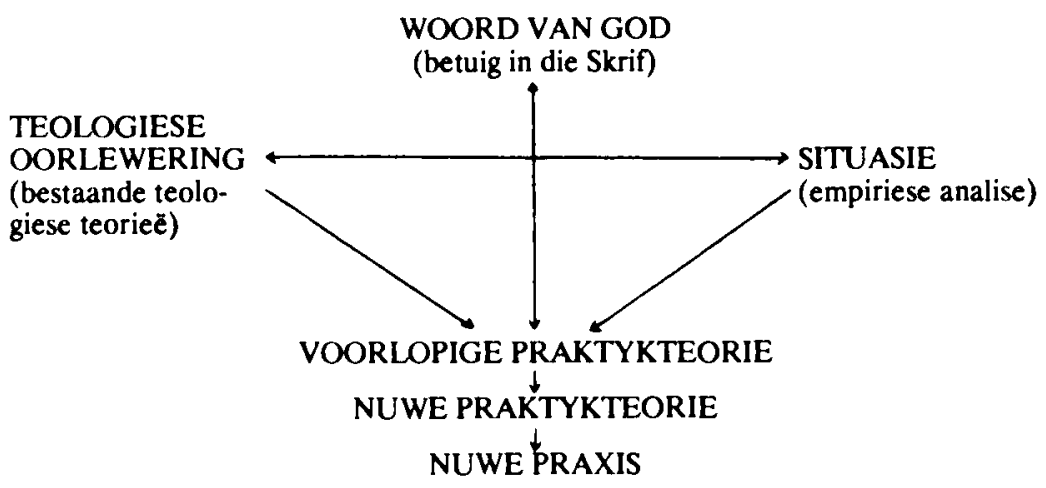




\section{SLOTOPMERKINGS}

Die outeurs van Eerste treë in die Prakaiese Teologie het met hulle publikasie tot die beoefening van die Praktiese Teologie in Suid-Afrika 'n groot bydrae gelewer. Ek aanvaar dat hulle nog steeds die Praktiese Teologie binne die teologiese fakulteit wil tuisbring. Indien die aanname korrek is, is hierdie kritiese opmerkings juis bedoel om die Praktiese Teologie sy teologiese aanspraak te laat behou. Die Praktiese Teologie speel ook 'n groot rol in die vorming en opleiding van toekomstige predikante. Om te voorkom dat hulle vanweë onduidelike aanwysings teologies ontspoor, is dit van die allergrootste belang dat die teologiese kwaliteit van die Praktiese Teologie in die basisteorie duidelik verwoord en in die metodologiese model eksplisiet verdiskonteer moet word.

\section{Literatuurverwysings}

De Wet, J I 1978. Die herlewing van 'n ou definisie van Praktiese Teologie. HTS 34, 5-11.

Firet, J 1975. Op weg naar theologisch existensie. Praktische Theologie 2, 378-386.

-.- 1987. Kroniek van de praktische theologie. Praktische Theologie 14, 552-567.

Heitink, G 1979. Pastoraat als hulpverlening. 2e druk. Kampen: Kok.

Heyns, L M \& Pieterse, H J C 1990. Eerste treë in die Praktiese Teologie. Pretoria: Gnosis.

Janson, J 1982. Praktiese Teologie, in Eybers, E, König, A \& Stoop J A (reds), Inleiding in die Teoiogie. Derde uitgawe. Pretoria: NG Kerkboekhandel.

Jonker, H 1983. Theologische Praxis. Nijkerk: Callenbach.

Jonker, W D 1981. In diens van die Woord. Pretoria: NG Kerkboekhandel.

Otto, G 1975. Praktisch Theologisches Handbuch. Hamburg: Rennebach.

Van der Ven, J A 1988. Practical theology from applied to empirical theology. Journal of Empirical Theology 1/1, 7-27.

Van Huyssteen, W 1986. Teologie as kritiese geloofsverantwoording: Teorievorming in die sistematiese teologie. Pretoria: RGN.

Van Wyk, A G 1989. 'n Evaluering van die grondslae van die diakonologiese benadering vanuit 'n prakties-teologiese perspektief. DTh-proefskrif, Universiteit van Suid-Afrika.

Velthuysen G C 1987. 'n Nuwe antwoord op 'n ou probleem: Die kritiese realisme van Wentzel van Huyssteen. HTS 43, 205-231.

Zerfass, R 1974. Praktische Theologie als Handlungswissenschaft: Praktische Theologie heute. München: Kaiser. 